\title{
BUDAYA ORGANISASI DAN KETERLIBATAN KERJA TERHADAP KOMITMEN ORGANISASI BERDAMPAK PADA KINERJA KARYAWAN PADA BTN - CIPUTAT
}

\author{
Jerry Marcellinus Logahan; Sherley Marcheline Aesaria
}

\author{
Management Department, School of Business Management, BINUS University \\ Jln. K.H. Syahdan No.9, Palmerah, Jakarta Barat 11480 \\ jerrymarcellinus@yahoo.com; jerryml@binus.ac.id
}

\begin{abstract}
PT. Bank Tabungan Negara, Tbk Ciputat branch is a company engaged in banking in Jakarta. As today's business competition, companies are competing to attract the attention of customers to use the services provided by PT. State Savings Bank, Tbk Ciputat branch. The purpose of this study was to determine the effect of organizational culture and job involvement on organizational commitment and its impact on the performance of employees at PT. State Savings Bank, Tbk Chester branch. The method used in this study is a path analysis. From the results of the data is found, the organizational culture has not been able to provide significant influence on organizational commitment while job involvement has a significant influence on organizational commitment. The next finding was found that organizational culture has a significant influence on employee performance. Later, it was found that job involvement has also a significant influence on employee performance. Furthermore, job involvement simultaneously influences organizational commitment. It was also found that organizational culture and job involvement simultaneously effect on the performance of employees at PT. Bank Tabungan Negara, Tbk Ciputat branch.
\end{abstract}

Keywords: organizational culture, job involvement, organizational commitment, employee performance

\begin{abstract}
ABSTRAK
PT. Bank Tabungan Negara, Tbk cabang Ciputat merupakan perusahaan yang bergerak di bidang perbankan di dalam menggunakan jasa yang diberikan oleh PT. Bank Tabungan Negara,Tbk cabang Ciputat. Tujuan penelitian ini adalah untuk mengetahui pengaruh budaya organisasi dan keterlibatan kerja terhadap komitmen organisasi dan dampaknya terhadap kinerja karyawan pada PT. Bank Tabungan Negara,Tbk cabang Ciputat. Metode yang digunakan dalam penelitian ini adalah path analysis. Dari hasil data ditemukan bahwa budaya organisasi belum mampu memberikan pengaruh secara signifikan terhadap komitmen organisasi. Sedangkan keterlibatan kerja memiliki pengaruh signifikan terhadap komitmen organisasi. Temuan berikutnya ditemukan bahwa budaya organisasi memiliki pengaruh secara signifikan terhadap kinerja karyawan. Kemudian ditemukan bahwa keterlibatan kerja memiliki pengaruh signifikan terhadap kinerja karyawan. Selanjutnya keterlibatan kerja berpengaruh secara simultan terhadap komitmen organisasi. Dan ditemukan juga bahwa budaya organisasi, dan keterlibatan kerja berpengaruh secara simultan terhadap kinerja karyawan pada PT. bank Tabungan Negara, Tbk cabang Ciputat
\end{abstract}

Kata kunci: budaya organisasi, keterlibatan kerja, komitmen organisasi, kinerja karyawan 


\section{PENDAHULUAN}

Saat ini dunia perbankan sedang mengalami persaingan yang tajam. Masing-masing perbankan berlomba-lomba mencari nasabah untuk dapat menggunakan jasanya, dan berbagai macam produk yang ditawarkan dunia perbankan mulai dari pendanaan kredit, investasi, asuransi, dsb. Tetapi hal yang ditawarkan belum bisa dapat menarik perhatian para nasabah. Ada sebagian perusahaan perbankan yang nasabahnya tidak sebanyak nasabah bank yang lainnya. Dari situ dapat dilihat bahwa nasabah tidak sembarangan menggunakan jasa perbankan, mereka melihat kinerja dari bank tersebut. PT. Bank Tabungan Negara, Tbk merupakan perusahaan yang bergerak dalam bidang perbankan. Yang melayani perbankan mulai dari pembiayaan kredit rumah, asuransi, tabungan,dsb. PT. Bank Tabungan Negara, Tbk sebagai perusahaan memiliki Visi dan Misi perusahaan yang menjadi dasar bagi perusahaan untuk menyusun strateginya dalam persaingan bisnis yang akan dijalankannya untuk dapat memenangkan persaiangan dalam bisnis perbankannya.

Visi dari Bank BTN yaitu "Untuk menjadi Bank terkemuka dalam pembiayaan perumahan”. Dengan adanya visi pasti ada misi perusahaan apa yang harus dilakukan oleh perusahaan sebagai berikut: (1) Memberikan pelayanan unggul dalam pembiayaan perumahan dan industri yang terkait, serta menyediakan produk dan jasa perbankan lainnya. (2) Menyiapkan dan mengembangkan sumber daya manusia yang berkualitas dan profesional serta memiliki integritas yang tinggi. (3) Meningkatkan keunggulan kompetitif melalui inovasi berkelanjutan sesuai dengan kebutuhan nasabah. (4) Melaksanakan manajemen perbankan yang sehat sesuai dengan prinsip kehati-hatian dan good corporate governance untuk meningkatkan shareholder values. (5) Memperdulikan kepentingan masyarakat dan llingkungannya.

Tabel 1 Laporan Persentase Performa Pelayanan Bank

\begin{tabular}{clccc}
\hline No & Keterangan & Tahun & Performa Costumer Service & Performa Teller \\
\hline 1 & Bank Mandiri & $2010 / 2011$ & 83,68 & 92,74 \\
& & $2011 / 2012$ & 82,47 & 87,95 \\
2 & Bank Permata & $2010 / 2011$ & 73,25 & 92,20 \\
& & $2011 / 2012$ & 75,04 & 88,44 \\
3 & Bank BNI & $2010 / 2011$ & 78,37 & 86,89 \\
& & $2011 / 2012$ & 72,79 & 83,30 \\
4 & Bank BRI & $2010 / 2011$ & 70,33 & 87,73 \\
& & $2011 / 2012$ & 71,51 & 83,61 \\
5 & Bank BII & $2010 / 2011$ & 80,05 & 90,60 \\
& & $2011 / 2012$ & 71,16 & 87,89 \\
6 & OCBC NISP & $2010 / 2011$ & 76,39 & 93,00 \\
& & $2011 / 2012$ & 69,17 & 86,49 \\
7 & CIMB NIAGA & $2010 / 2011$ & 75,32 & 90,20 \\
& & $2011 / 2012$ & 68,57 & 83,36 \\
8 & Bank Danamon & $2010 / 2011$ & 60,68 & 84,33 \\
& & $2011 / 2012$ & 65,67 & 92,02 \\
9 & Bank BCA & $2010 / 2011$ & 68,83 & 86,73 \\
& & $2011 / 2012$ & 59,38 & 79,81 \\
10 & Bank BTN & $2010 / 2011$ & 52,43 & 83,01 \\
& & $2011 / 2012$ & 50,10 & 83,02 \\
\hline
\end{tabular}

Sumber: Infobank no. 398 Mei 2012 
Data di atas menunjukkan bahwa PT. Bank Tabungan Negara, Tbk belum mampu meningkatkan kinerja dalam persaingan perbankan pada saat ini. Performanya masih belum menempati peringkat pertama. Dalam menghadapi persaingan perbankan yang kian melesat tajam tersebut, perusahaan dituntut untuk dapat meningkatkan kualitas sumber daya manusia, agar kinerja perusahaan secara keseluruhan dapat unggul dalam daya saing industri perbankan.

Sumber daya manusia memegang peranan penting dalam mendukung operasional perusahaan. Organisasi harus memfokuskan dalam sumber daya manusia guna menjalankan fungsinya dengan optimal. Seperti yang dikatakan oleh Sudarmadi (2007):

"Budaya organisasi berpengaruh positif terhadap kinerja karyawan. Dengan sumber daya yang dapat menjalankan fungsinya maka organisasi dapat menghadapi perubahan secara teknis, teoritis, konseptual, dan moral para pelaku organisasi dalam suatu tingkatan kerja dari organisasi. Meningkatkan sumber daya manusia dapat dilakukan dengan menciptakan budaya organisasi dimana budaya organisasi sangat penting bagi manajemen bila ingin mencapai kinerja yang tinggi, yang pada akhirnya tercipta sikap kerja yang positif yang mendorong peningkatan kinerja karyawan dan manajemen, diwujudkan dalam seluruh aktifitas dan kebijakan perusahaan. Budaya organisasi yang dibuat diikuti oleh seluruh karyawan, dengan adanya budaya organisasi dapat menjadikan suatu ciri tersendiri dari setiap organisasi”

Dalam suatu perusahaan ataupun organisasi keterlibatan kerja karyawan juga sangat berperan besar. Menurut Setiani (2010):

“Ada pengaruh yang signifikan keterlibatan kerja dan komitmen organisasi terhadap kinerja. Dimana seorang karyawan mengidentifikasi diri secara psikologis dengan pekerjaannya, dan menganggap kinerjanya penting untuk dirinya, selain untuk organisasi. Berdasarkan teori diatas menunjukkan bahwa dengan mengetahui keinginan kerja karyawannya, maka para karyawannya akan menjadi lebih termotivasi, lebih berkomitmen terhadap organisasi ataupun perusahaan, lebih produktif dan lebih puas dengan pekerjaan mereka. Dengan adanya keterlibatan kerja akan mengakibatkan pencapaian sasaran dan tujuan organisasi, dimana jika karyawan menganggap pekerjaan merupakan kebutuhannya ia akan lebih memfokuskan dirinya tehadap pekerjaannya dan akan lebih ingin menjadi yang terbaik untuk dirinya, dengan adanya anggapan dari seorang karyawan seiring waktu kinerja karyawan pun akan meningkat dan sasaran dan tujuan organisasi akan lebih cepat tercapainya”.

Tidak hanya budaya organisasi dan keterlibatan saja yang dapat mempengaruhi dalam peningkatan kinerja karyawan. Mandan Momeni, Amir dan Saadat (2012) menyatakan bahwa "Hasil dari studi menunjukkan bahwa ada hubungan yang signifikan antara semua komponen budaya organisasi termasuk adaptasi, keterlibatan, penyesuaian, misi dan komitmen organisasi”. Begitu juga yang dikatakan oleh Shah, Memon, dan Phulpoto (2012) bahwa "Hasil hubungan yang positif dan signifikan yang signifikan antara semua variabel termasuk sub budaya inovasi organisasi dan pengambilan risiko, perhatian terhadap detail, orientasi hasil, orientasi orang dan tim orientasi dengan semua sub-variabel komitmen organisasi”. Sedangkan Triyono (2008) menyatakan bahwa:

"Komitmen organisasi tidak mempunyai pengaruh yang signifikan terhadap kinerja pegawai pada PT Bank BRI (Persero) Tbk Kantor Cab. Klaten. Komitmen organisasi juga terkait dengan peningkatan kinerja karyawan, dengan adanya komitmen organisasi dapat melihat bahwa seberapa besarnya pengabdian karyawan tehadap organisasi. Hal tersebut tekait dengan hasil dari keterlibatan kerja, dimana keterlibatan kerja merupakan cara mereka bertindak dalam menghadapi situasi pekerjaan dan komitmen organisasi merupakan pendirian yang dimiliki untuk dapat beradaptasi 
dalam organisasinya. Kinerja karyawan merupakan suatu varibel yang dapat mempengaruhi sukses atau tidaknya sebuah perusahaan. Begitu juga dengan komitmen organisasi, dimana karyawan memfokuskan diri atau rasa cinta kepada perusahaannya untuk kemajuan dari perusahaannya”.

Dengan melihat bahwa budaya organisasi, keterlibatan kerja, dan komitmen organisasi berpengaruh besar terhadap kinerja karyawan pada organisasi. Dan berdasarkan data laporan performa PT. Bank Tabungan Negara, Tbk yang belum mencapai pada visi misi yang dirumuskan. Oleh karena itu penelitian dilakukan untuk menganalisis Pengaruh Budaya Organisasi dan Keterlibatan Kerja terhadap Komitmen Organisasi dan Dampaknya terhadap Kinerja Karyawan pada PT. Bank Tabungan Negara, Tbk cabang Ciputat.

\title{
Tujuan Penelitian
}

Tujuan penelitian ini adalah untuk mengetahui: (1) Pengaruh budaya organisasi terhadap komitmen organisasi PT. Bank Tabungan Negara, Tbk cabang Ciputat. Untuk meningkatkan komitmen organisasi budaya organisasi perlu ditingkatkan di PT. Bank Tabungan Negara. (2) Pengaruh keterlibatan kerja terhadap komitmen organisasi PT. Bank Tabungan Negara, Tbk cabang Ciputat. Untuk meningkatkan komitmen organisasi keterlibatan kerja perlu ditingkatkan di PT. Bank Tabungan Negara. (3) Pengaruh budaya organisasi dan keterlibatan kerja terhadap komitmen organisasi (Y) PT. Bank Tabungan Negara, Tbk cabang Ciputat. Untuk meningkatkan komitmen organisasi budaya organisasi dan keterlibatan kerja perlu ditingkatkan di PT. Bank Tabungan Negara. (4) Pengaruh budaya organisasi terhadap kinerja karyawan PT. Bank Tabungan Negara, Tbk cabang Ciputat. Untuk meningkatkan kinerja karyawan budaya organisasi perlu ditingkatkan di PT. Bank Tabungan Negara. (5) Pengaruh keterlibatan kerja terhadap kinerja karyawan PT. Bank Tabungan Negara, Tbk cabang Ciputat. Untuk meningkatkan kinerja karyawan keterlibatan kerja perlu ditingkatkan di PT. Bank Tabungan Negara. (6) Pengaruh komitmen organisasi terhadap kinerja karyawan PT. Bank Tabungan Negara, Tbk cabang Ciputat. Untuk meningkatkan kinerja karyawan komitmen organisasi perlu ditingkatkan di PT. Bank Tabungan Negara. (7) Pengaruh budaya organisasi, keterlibatan kerja dan komitmen organisasi terhadap kinerja karyawan PT. Bank Tabungan Negara, Tbk cabang Ciputat. Untuk meningkatkan kinerja karyawan budaya organisasi, keterlibatan kerja dan komitmen organisasi perlu ditingkatkan di PT. Bank Tabungan Negara.

\section{Konseptual}

Budaya organisasi menurut Robbins dan Judge (2003) merupakan:

\begin{abstract}
"Sistem makna bersama terhadap nilai-nilai primer yang dianut bersama dan dihargai organisasi, yang berfungsi menciptakan pembedaan yang jelas antara satu organisasi dengan organisasi lainnya, menciptakan rasa identitas bagi para anggota organisasi, mempermudah timbulnya komitmen kolektif terhadap organisasi, meningkatkan kemantapan sistem sosial, serta menciptakan mekanisme pembuat makna dan kendali yang memandu membentuk sikap dan perilaku para anggota organisasi”.
\end{abstract}

Menurut Robbins and Judge (2003), ada 7 ciri-ciri budaya organisasi adalah: (1) Inovasi dan pengambilan resiko. Suatu tingkatan dimana pekerja didorong untuk menjadi inovatif dan mengambil risiko. (2) Perhatian pada hal detail. Di mana pekerja diharapkan menunjukkan ketepatan, analisis, dan perhatian pada hal detail. (3) Orientasi pada manfaat. Di mana manajemen memfokus pada hasil atau manfaat daripada sekedar pada teknik dan proses yang dipergunakan untuk mendapatkan manfaat tersebut. (4) Orientasi pada orang. Di mana keputusan manajemen mempertimbangkan pengaruh manfaat keputusan manajemen pada orang dalam organisasi. (5) Orientasi pada tim. Di mana aktivitas kerja diorganisasi lebih berdasarkan pada tim daripada individual. (6) Agresivitas. Di mana orang 
cenderung lebih agresif dan kompetitif dari pada easygoing. (7) Stabilitas. Di mana aktivitas organisasional menekankan pada menjaga status quo sebagai lawan dari perkembangan.

\section{Robinowitz dan Hall (dalam Kanungo, 1982) mendefinisikan}

"Keterlibatan kerja ke dalam dua kategori. Pertama, keterlibatkan kerja dipandang sebagai suatu performance self-esteem contingency, di mana menurut definisi ini keterlibatan kerja adalah tingkat sampai sejauh mana harga diri (self-esteem) individu dipengaruhi oleh tingkat performansinya ketika bekerja”.

Sehingga, keterlibatan kerja yang lebih tinggi atau keterlibatan kerja yang lebih rendah menunjukkan harga diri yang lebih rendah atau tinggi yang diperoleh ketika bekerja. Kedua, keterlibatan kerja sebagai suatu identifikasi psikologis dengan pekerjaan seseorang.

Menurut Robinowitz dan Hall (Dalam Kanungo, 1982), faktor-faktor yang mempengaruhi keterlibatan kerja adalah sebagai berikut: (1) Keterlibatan kerja sebagai karakteristik personal, antara lain: (Usia ,Tingkat pendidikan, Status perkawinan, Jenis kelamin, Locus of control, Higher order need strength). (2) Keterlibatan kerja sebagai karakteristik situasional, antara lain: (Kepuasan kerja, Masa kerja, Turn over dan absebteeism, Kebutuhan finansial). (3) Keterlibatan kerja sebagai hasil interaksi individu dengan lingkungan; hubungan yang terjadi antara individu dengan lingkungan, hubungan ini akan mengakibatkan suatu efek secara langsung maupun tidak langsung terhadap diri individu untuk terlibat pada pekerjaannya.

Steers (Dalam Sri Kuntjoro, 2002) mendefinisikan:

"Komitmen organisasi sebagai rasa identifikasi (kepercayaan terhadap nilai-nilai organisasi), keterlibatan (kesediaan untuk berusaha sebaik mungkin demi kepentingan organisasi) dan loyalitas (keinginan untuk tetap menjadi anggota organisasi yang bersangkutan) yang dinyatakan oleh seorang pegawai terhadap organisasinya”.

Steers berpendapat bahwa komitmen organisasi merupakan kondisi di mana pegawai sangat tertarik terhadap tujuan, nilai-nilai, dan sasaran organisasi. Komitmen terhadap organisasi berarti lebih dari sekedar keanggotaan formal, karena meliputi sikap menyukai organisasi dan kesediaan untuk mengusahakan tingkat upaya yang tinggi bagi kepentingan organisasi demi pencapaian tujuan. Curtis and Wright (2001) menjelaskan bahwa konsep ini dapat dipecah menjadi dua komponen, yaitu: (1) Keinginan memelihara keanggotaan dalam organisasi. (2) Keyakinan dan penerimaan terhadap nilai dan tujuan organisasi.

Menurut Mangkunegara (2000) "Kinerja adalah hasil kerja secara kualitas dan kuantitas yang dicapai oleh seorang karyawan dalam melaksanakan tugasnya sesuai dengan tanggung jawab yang diberikannya”. Menurut Mangkunegara (2006) terdapat aspek-aspek standar pekerjaan yang terdiri dari aspek kuantitatif dan aspek kualitatif meliputi : (1) Aspek kuantitatif yaitu: proses kerja dan kondisi pekerjaan, waktu yang dipergunakan atau lamanya melaksanakan pekerjaan, jumlah kesalahan dalam melaksanakan pekerjaan, dan jumlah dan jenis pemberian pelayanan dalam bekerja. (2) Aspek kualitatif yaitu: ketepatan kerja dan kualitas pekerjaan, tingkat kemampuan dalam bekerja, dan kemampuan menganalisis data/informasi, kemampuan/kegagalan menggunakan mesin/peralatan, dan kemampuan mengevaluasi (keluhan/keberatan konsumen/masyarakat). 


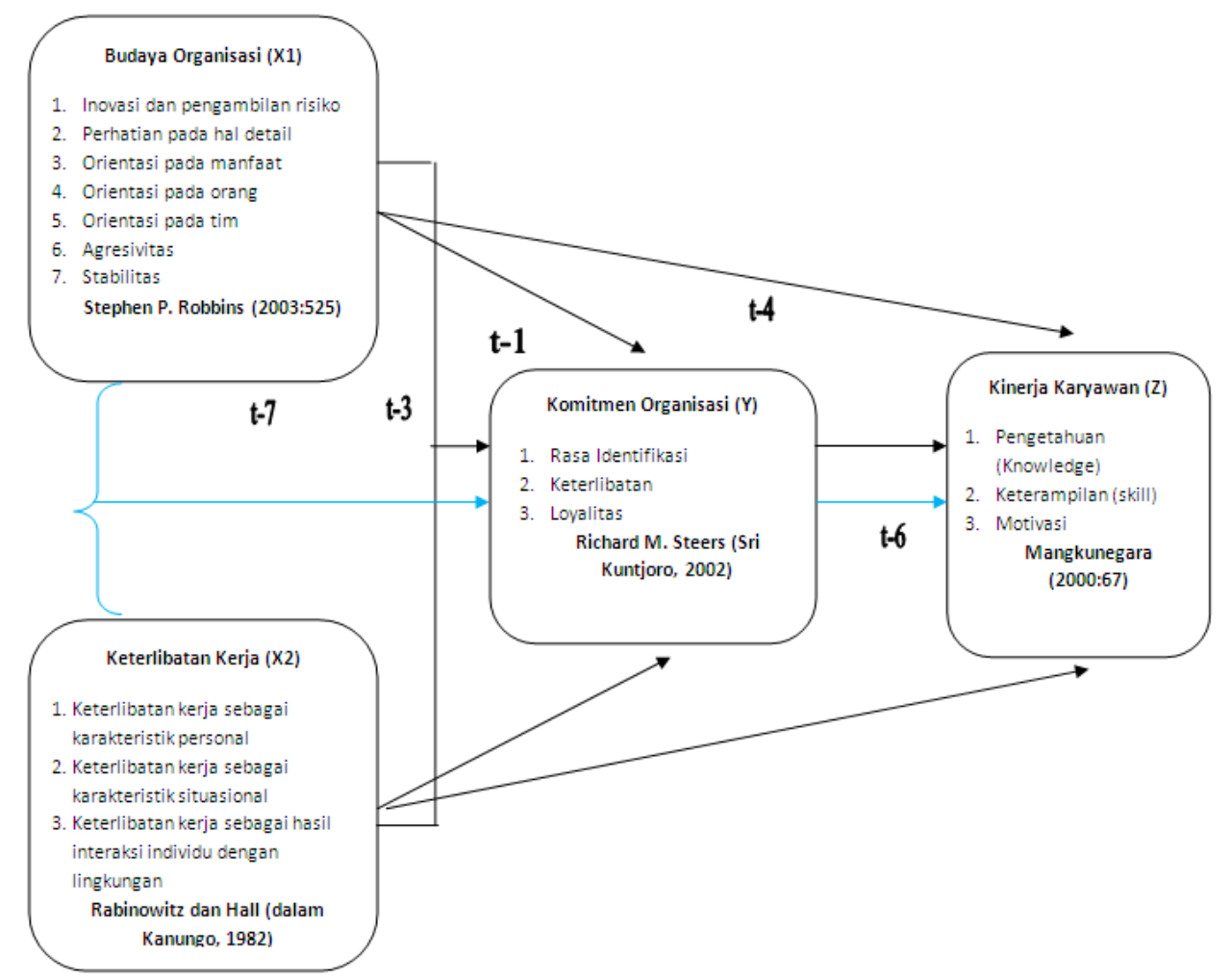

Gambar 1 Kerangka Pemikiran Sumber: Penulis (2013)

Hipotesis merupakan jawaban sementara terhadap rumusan masalah penelitian, di mana rumusan masalah penelitian telah dinyatakan dalam bentuk kalimat pertanyaan. Dikatakan sementara, karena jawaban yang diberikan baru didasarkan pada teori yang relevan, belum didasarkan pada faktafakta empiris yang diperoleh melalui pengumpulan data. Jadi hipotesis juga dapat dinyatakan sebagai jawaban teoritis terhadap rumusan masalah penelitian, belum jawaban yang empirik. Adapun hipotesis yang diajukan dalam penelitian ini adalah sebagai berikut:

t-1 : Pengaruh budaya organisasi (X1) terhadap komitmen organisasi (Y) PT. Bank Tabungan Negara, Tbk cabang Ciputat.

t-2 : Pengaruh keterlibatan kerja (X2) terhadap komitmen organisasi (Y) PT. Bank Tabungan Negara, Tbk cabang Ciputat.

t-3 : Pengaruh budaya organisasi (X1) dan keterlibatan kerja (X2) terhadap komitmen organisasi (Y) PT. Bank Tabungan Negara, Tbk cabang Ciputat

t-4 : Pengaruh budaya organisasi (X1) terhadap kinerja karyawan (Z) PT. Bank Tabungan Negara, Tbk cabang Ciputat.

t-5 : Pengaruh keterlibatan kerja (X2) terhadap kinerja karyawan (Z) PT. Bank Tabungan Negara, Tbk cabang Ciputat.

t-6 : Pengaruh komitmen organisasi (Y) terhadap kinerja karyawan (Z) PT. Bank Tabungan Negara, Tbk cabang Ciputat.

t-7 : Pengaruh budaya organisasi (X1), keterlibatan kerja (X2) dan komitmen organisasi (Y) terhadap kinerja karyawan (Z) PT. Bank Tabungan Negara, Tbk cabang Ciputat. 


\section{METODE}

Jenis penelitian adalah Asosiatif. Unit analisis Karyawan PT. Bank Tabungan Negara, Tbk cabang Ciputat. Time horizon yang digunakan adalah cross sectional. Jenis data adalah kuantitatif dan kualitatif. Teknik pengumpulan data adalah wawancara, kuesioner, pengamatan dan studi pustaka. Populasi 115 karyawan. Penarikan sampel menggunakan rumus Slovin adalah sebagai berikut:

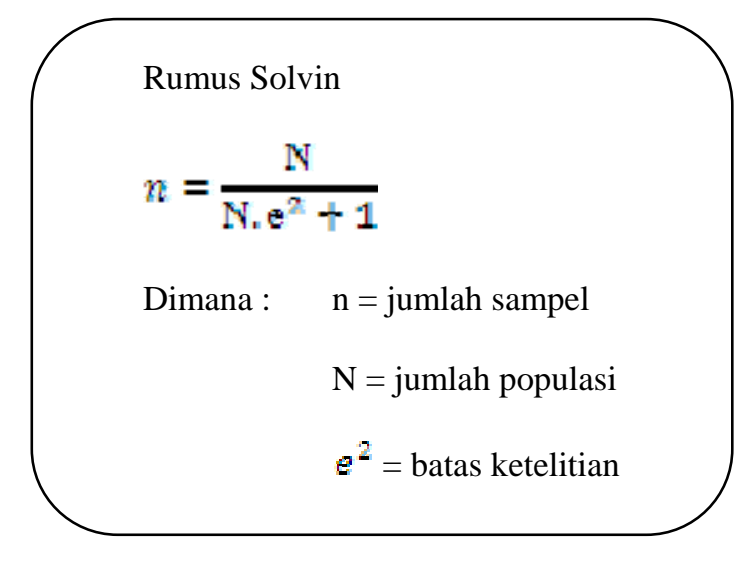

Gambar 2 Rumus Slovin

Sumber: Sarwono, Jonathan. (2012)

Dengan menggunakan rumus slovin maka didapat sampel sebesar :

$$
n=\frac{115}{115 .(0.1)^{2}+1}=\frac{115}{115(0.01)+1}=\frac{115}{1.15+1}=\frac{115}{2.15}=53.4=54
$$

Maka dalam penelitian ini sampel sebesar 54 responden karyawan PT. Bank Tabungan Negara,Tbk cabang Ciputat diambil. Dan metode analisis menggunakan path analysis.

\section{HASIL PEMBAHASAN}

Jadi keseluruhan pengaruh kasual variabel Budaya Organisasi $\left(X_{1}\right)$, Keterlibatan Kerja $\left(X_{2}\right)$ terhadap Komitmen Organisasi $\left(\boldsymbol{Y}^{2}\right)$ dan dampaknya pada Kinerja Karyawan (Z) PT. Bank Tabungan Negara, Tbk cabang Ciputat setelah dilakukan triming dapat digambarkan dalam model struktur lengkap sebagai berikut: 


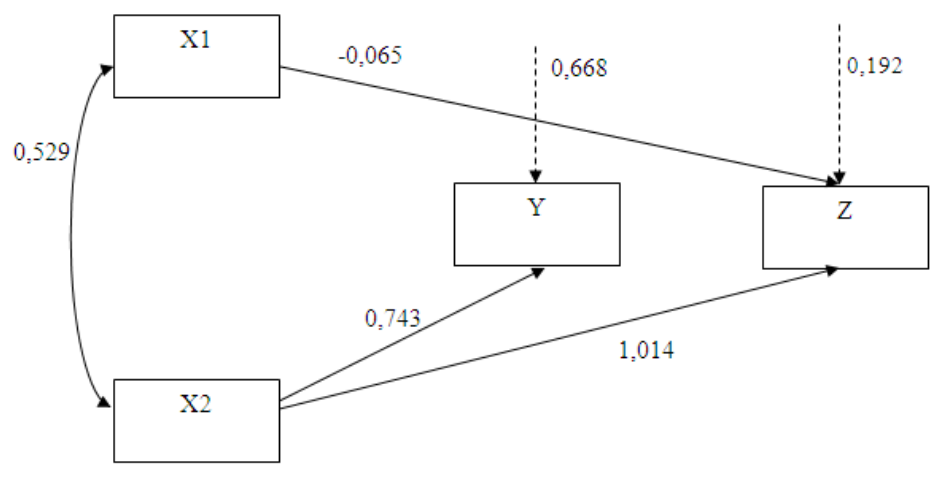

Gambar 3 Hasil Path Analysis

Sumber: Hasil Pengolahan Data Penelitian, 2012

Keseluruhan Sub-Struktural Setelah trimming Beserta Koefisien Jalur

Tabel 2 Rangkuman Pengaruh Budaya Organisasi $\left(\underline{X_{f}}\right)$,Keterlibatan Kerja $\left(\boldsymbol{X}_{\mathbf{n}}\right)$

terhadap Komitmen Organisasi_( $(\mathrm{Y})$ dan dampaknya

pada Kinerja Karyawan_(Z) PT. Bank Tabungan Negara, Tbk cabang Ciputat

\begin{tabular}{ccccc}
\hline Variabel & Koefisien & \multicolumn{3}{c}{ Pengaruh } \\
\cline { 3 - 5 } & Jalur & Langsung & Tidak Langsung & Total \\
\hline X1 terhadap Y & $-0,172$ & $-0,172$ & - & $-0,172$ \\
X2 terhadap Y & 0,743 & 0,743 & - & 0,743 \\
X1 terhadap Z & $-0,065$ & $-0,065$ & $-0,172 \mathrm{X}-0,011=0,147651$ & 0,0826 \\
X2 terhadap Z & 1,014 & 1,014 & $0,743 \mathrm{X}-0,011=-0,00183$ & 1,012 \\
Y terhadap Z & $-0,011$ & $-0,011$ & - & $-0,011$ \\
$\mathbf{P}_{y} \mathbf{z}_{1}$ & - & - & - & 0,668 \\
$\mathbf{P}_{y} \mathbf{z}_{2}$ & - & - & - & 0,192 \\
\hline
\end{tabular}

Sumber: Hasil Pengolahan Data Penelitian, 2012

Berdasarkan Tabel 2, maka dapat ditarik kesimpulan bahwa Hipotesis pertama yang berbunyi "Budaya Organisasi $\left(X_{1}\right)$, dan Keterlibatan Kerja $\left(X_{2}\right)$ memiliki pengaruh secara signifikan secara simultan terhadap Komitmen Organisasi $\left(Y^{\prime}\right)$ pada PT. Bank Tabungan Negara,Tbk”, bahwa secara keseluruhan menyatakan signifikan. Namun, secara individual tidak semua sub-variabel diterima, karena beradasarkan pengujian sub-struktural 1, koefisien jalur $X_{1}$ terhadap $Y$ secara statistik tidak signifikan. Sedangkan koefisien $X_{2}$ terhadap $Y$ signifikan. Dengan demikian hasil temuan analisis ini memberikan informasi bahwa Keterlibatan Kerja $\left(X_{2}\right)$ memiliki hubungan yang signifikan secara simultan terhadap Komitmen Organisasi $(Y$ ) pada PT. Bank Tabungan Negara,Tbk. Besarnya kontribusi Keterlibatan Kerja $\left(X_{2}\right)$ terhadap Komitmen Organisasi $(Y)$ sebesar $0,743^{2} \times 100 \%=$ $55,20 \%$ dan sisanya $0,668^{2} \times 100 \%=44,62 \%$ merupakan kontribusi dari variabel lain di luar penelitian ini.

Hipotesis kedua yang berbunyi "Budaya Organisasi $\left(X_{1}\right)$, Keterlibatan Kerja $\left(X_{2}\right)$ serta Komitmen Organisasi $(Y)$ memiliki pengaruh yang signifikan secara simultan terhadap Kinerja Karyawan $(Z)$ pada PT. Bank Tabungan Negara, Tbk cabang Ciputat”, bahwa secara keseluruhan 
menyatakan signifikan. Namun, secara individual tidak semua sub-variabel diterima, karena berdasarkan pengujian sub-struktural 2 model 1, koefisien jalur $\boldsymbol{Y}$ terhadap $Z$ secara statistik tidak signifikan. Sedangkan koefisien $X_{1}$ dan $X_{2}$ secara statistik adalah signifikan. Dengan demikian, dapat diperoleh informasi bahwa Budaya Organisasi $\left(X_{1}\right)$ dan Keterlibatan Kerja $\left(\boldsymbol{X}_{2}\right)$ memiliki hubungan yang signifikan secara simultan terhadap Kinerja Karyawan $(z)$. Besarnya pengaruh Budaya Organisasi $\left(X_{1}\right)$ terhadap Kinerja Karyawan $(z)$ sebesar $(-0,065)^{2} \times 100 \%=0,4225$, pengaruh Keterlibatan Kerja $\left(X_{2}\right)$ terhadap Kinerja Karyawan $(Z)$ sebesar $1,014^{2}$ x $100 \%=102,81 \%$. Sedangkan besarnya pengaruh signifikan Budaya Organisasi $\left(X_{1}\right)$ dan Keterlibatan Kerja $\left(X_{2}\right)$ secara simultan yang langsung mempengaruhi Kinerja Karyawan $(z)$ adalah $96,3 \%$ dan sisanya $0,192^{2} \mathrm{x}$ $100 \%=3,68 \%$ dipengaruhi oleh faktor-faktor lain diluar penelitian ini.

Setelah semua data telah dikumpulkan dan hasil analisis selesai dilakukan, pertama-tama diperoleh hasil bahwa budaya organisasi yang diterapkan pada perusahaan baik dan secara umum berarti karyawan PT. Bank Tabungan Negara, Tbk cabang Ciputat dapat menerima dan mampu menjalankan budaya organisasi yang diterapkan. Keterlibatan kerja karyawan PT. Bank Tabungan Negara,Tbk cabang Ciputat termasuk baik dan secara keseluruhan tidak terdapat keberagaman yang terlalu tinggi diantara para karyawan PT. Bank Tabungan Negara,Tbk cabang Ciputat. Komitmen Organisasi pada PT. Bank Tabungan Negara,Tbk juga termasuk baik, berarti secara umum perusahaan membuat karyawannya nyaman dalam perusahaan dan jawaban mereka juga cenderung seragam. Hal ini sejalan dengan Kinerja Karyawan PT. Bank Tabungan Negara,Tbk cabang Ciputat yang menunjukkan tingkatan yang baik, dan jawaban karyawan juga cenderung seragam.

Selanjutnya, setelah hasil kuesioner selesai dianalisis dengan analisis jalur, diperoleh hasil sebagai berikut:

\section{Budaya Organisasi $\left(X_{1}\right)$ tidak memiliki pengaruh secara signifikan dan negatif terhadap Komitmen Organisasi $(Y)$}

Dari hasil penelitian ini menunjukkan bawah Budaya Organisasi tidak memiliki pengaruh secara signifikan dan negatif terhadap Komitmen Organisasi pada PT. Bank Tabungan Negara,Tbk cabang Ciputat. Selain itu Budaya Organisasi juga memiliki hubungan yang sangat rendah dan tidak signifikan dengan Komitmen Organisasi. Hal ini berarti dengan hubungan budaya organisasi berbanding terbalik dengan komitmen organisasi. Ini berarti, jika budaya organisasi semakin baik, maka komitmen organisasi akan menurun. Begitu juga sebaliknya jika komitmen organisasi meningkat, maka budaya organisasi menurun. Sebaiknya perusahaan harus memperhatikan kedua hal tersebut agar dapat meningkat keduanya. Dalam meningkatkan budaya organisasi sebaiknya perusahaan memberikan kebebasan kepada karyawan dalam bertindak selama tidak merugikan perusahaan dan masih dalam ruang lingkup untuk meningkatkan kemajuan perusahaan. Sedangkan untuk meningkatkan komitmen organisasi sebaiknya perusahaan memperbaiki sistem kerja yang ada, agar karyawan memberikan kontribusi yang lebih lagi.

\section{Keterlibatan Kerja $\left(X_{2}\right)$ memiliki pengaruh secara signifikan dan positif terhadap Komitmen Organisasi $(Y)$}

Dari hasil penelitian ini menunjukkan bahwa keterlibatan kerja memiliki pengaruh signifikan dan positif terhadap komitmen organisasi pada PT. Bank Tabungan Negara,Tbk cabang Ciputat. Selain itu, keterlibatan kerja juga memiliki hubungan yang kuat dan signifikan terhadap komitmen organisasi. Hal ini berarti, semakin besar tingkat keterlibatan kerja karyawan, maka sudah pasti komitmen organisasi yang dimiliki karyawan juga akan meningkat. Dari hasil kuesioner variabel X2 
diketahui bahwa rata-rata skor paling rendah dari 12 sub-variabel adalah ke-2 yaitu tentang tingkat pendidikan dalam keterlibatan kerja. Butir pertanyaan yang memiliki total skor paling rendah adalah butir 2, dimana butir tersebut menyatakan bahwa dalam tingkat pendidikan saya saat ini membuat keterlibatan kerja saya semakin baik. Hal ini menunjukkan bahwa tingkat pendidikan yang dimiliki karyawan tidak dapat membuat keterlibatan kerja meningkat. Oleh karena itu, perusahaan harus melakukan sistem penghargaan kepada karyawan. Dimana seluruh karyawan diberikan pengetahuanpengetahuan mengenai perbankan dengan sering melibatkan karyawan dalam seminar perbankan dari perusahaan tanpa memandang seperti apa pendidikan yang dimiliki karyawan.

\section{Budaya Organisasi $\left(X_{1}\right)$ memiliki pengaruh secara signifikan dan hubungan yang negatif terhadap Kinerja Karyawan $(z)$}

Dari hasil penelitian ini menunjukkan bahwa budaya organisasi memiliki pengaruh secara signifikan dan negatif terhadap kinerja karyawan pada PT. Bank Tabungan Negara,Tbk cabang Ciputat. Selain itu, budaya organisasi juga memiliki hubungan yang cukup kuat dan signifikan terhadap kinerja karyawan. Hal ini berarti, berbanding terbalik hubungan antara budaya organisasi dengan kinerja karyawan,tidak searah. Semakin meningkat budaya organisasi, maka kinerja karyawan yang dimiliki karyawan menurun. Dari hasil kuesioner variabel X1 rata-rata skor paling rendah yaitu pada butir ke-2 yang menyatakan bahwa pemimpin memberi saya kebebasan dalam bertindak untuk berani mengambil risiko. Hal ini menunjukkan bahwa inovasi dan pengambilan risiko yang dimiliki karyawan tidak dapat membuat budaya organisasi meningkat. Oleh karena itu, perusahaan harusnya lebih selektif lagi dalam memberikan kebebasan kepada karyawan untuk mengambil sebuah keputusan.

\section{Keterlibatan Kerja $\left(X_{2}\right)$ memiliki pengaruh secara signifikan dan hubungan yang positif terhadap Kinerja Karyawan $(z)$}

Dari hasil penelitian ini menunjukkan bahwa keterlibatan kerja memiliki pengaruh secara signifikan dan positif terhadap kinerja karyawan pada PT. Bank Tabungan Negara,Tbk cabang Ciputat. Selain itu, keterlibatan kerja juga memiliki hubungan yang sangat kuat dan signifikan terhadap kinerja karyawan. Hal ini berarti, semakin baik keterlibatan kerja, maka kinerja karyawan yang dimiliki karyawan juga akan meningkat. Dari hasil kuesioner variabel X2 rata-rata skor paling rendah yaitu pada butir ke-2 yang menyatakan bahwa dalam tingkat pendidikan saya saat ini membuat keterlibatan kerja saya semakin baik. Hal ini menunjukkan bahwa tingkat pendidikan yang dimiliki karyawan tidak dapat membuat kinerja karyawan meningkat. Dalam ini berarti karyawan merasa tertekan atas tugas yang diberikan perusahaan tanpa adanya toleransi. Oleh karena itu, perusahaan harus meningkatkan toleransi kepada karyawan terhadap tugas yang dikerja oleh karyawan.

\section{Komitmen Organisasi $(\mathscr{C})$ tidak memiliki pengaruh secara signifikan dan hubungan yang negatif terhadap Kinerja Karyawan $(Z)$}

Dari hasil penelitian ini menunjukkan bahwa komitmen organisasi tidak memiliki pengaruh secara signifikan dan negatif terhadap kinerja karyawan pada PT. Bank Tabungan Negara,Tbk cabang Ciputat. Selain itu, komitmen organisasi juga memiliki hubungan yang sangat rendah dan tidak signifikan terhadap kinerja karyawan. Dalam hal ini rata-rata skor yang paling rendah adalah pada variabel (Z) yang menyatakan bahwa saya dapat memberikan pelayanan dalam waktu minimal 5 menit perorang. Hasil tersebut membuktikan bahwa karyawan tidak dapat bekerja secara minimal waktu 5 menit. Maka dari itu Perusahaan harusnya memperhatikan kedua hal tersebut walaupun tidak memiliki kontribusi secara signifikan. Dalam hal ini perusahaan seharusnya melakukan pelatihan lagi kepada karyawan, agar dapat meningkatkan pelayanan yang lebih cepat lagi. 


\section{SIMPULAN}

Dari penelitian yang telah dilakukan, maka dapat disimpulkan bahwa Budaya Organisasi tidak berpengaruh signifikan terhadap Komitmen Organisasi pada PT. Bank Tabungan Negara,Tbk cabang Ciputat sebesar $-17,4 \%$. Artinya, pengaruh budaya organisasi terhadap komitmen organisasi memiliki pengaruh $-17,4 \%$, dan sisanya dipengaruhi oleh faktor lain diluar penilitian ini. Keterlibatan Kerja berpengaruh signifikan terhadap Komitmen Organisasi pada PT. Bank Tabungan Negara, Tbk cabang Ciputat sebesar $74,3 \%$. Artinya, keterlibatan kerja memliki pengaruh terhadap komitmen oragnisasi sebesar 74,3\%, dan sisanya dipengaruhi oleh faktor lain diluar penelitian ini.

Budaya Organisasi berpengaruh signifikan terhadap Kinerja Karyawan pada PT. Bank Tabungan Negara,Tbk cabang Ciputat sebesar -6,5\%. Artinya, besar pengaruh yang dimiliki dari variabel budaya oragnisasi terhadap kinerja karyawan sebesar $-6,5 \%$ dan sisanya dipengaruhi oleh faktor lain diluar pennelitian ini. Keterlibatan Kerja berpengaruh signifikan terhadap Kinerja Karyawan pada PT. Bank Tabungan Negara,Tbk cabang Ciputat sebesar 101,4\%. Artinya, variabel keterlibatan kerja berpengaruh terhadap kinerja karyawan sebesar $101,4 \%$ dan sisanya dipengaruhi oleh faktor lain.

Komitmen Organisasi tidak berpengaruh signifikan terhadap Kinerja Karyawan pada PT. Bank Tabungan Negara,Tbk cabang Ciputat sebesar -1,1\%. Variabel komitmen organisasi mempengaruhi variabel kinerja sebesar $-1,1 \%$ tetapi tidak memiliki pengaruh dengan signifikan, dan sisanya dipengaruhi oleh faktor lain diluar penelitian ini. Budaya Organisasi dan Keterlibatan Kerja berpengaruh secara simultan terhadap Komitmen Organisasi pada PT. Bank Tabungan Negara,Tbk cabang Ciputat sebesar 55,3\%. Artinya, besarnya pengaruh budaya oragnisasi dan keterlibatan kerja terhadap komitmen organisasi adalah sebesar 55,3\% dan sisanya dipengaruhi oleh faktor lain diluar penelitian ini sebesar $44,7 \%$.

Budaya Organisasi, Keterlibatan Kerja serta Komitmen Organisasi berpengaruh secara simultan terhadap Kinerja Karyawan pada PT. Bank Tabungan Negara,Tbk cabang Ciputat sebesar 96,3\%. Artinya, budaya organisasi, keterlibatan kerja serta komitmen organisasi memiliki pengaruh terhadap kinerja karyawan sebesar 96,3\% dan sisanya dipengaruhi oleh faktor lain diluar penelitian ini sebesar 3,7\%.

Dari hasil penelitian yang telah dilakukan, PT. Bank Tabungan Negara,Tbk cabang Ciputat disarankan untuk tetap memperhatikan budaya organisasi dan komitmen organisasi yang dimiliki, walaupun tidak memiliki kontribusi yang signifikan. Dalam upaya meningkatkan budaya organisasi, sebaiknya PT. Bank Tabungan Negara,Tbk cabang Ciputat memberikan kebebasan kepada karyawan untuk bisa mengambil keputusan, agar mereka merasa bahwa mereka diberikan andil dalam perusahaan. Untuk meningkatkan komitmen organisasi ketika budaya organisasi meningkat, sebaiknya perusahaan memperbaiki sistem kerja yang ada, agar karyawan memberikan kontribusi yang lebih lagi. Perubahan sistem kerja misalnya peraturan dalam melakukan pekerjaan lebih diperketat, seperti teller yang harus memberikan pelayanan kepada nasabah dibawah 5 menit dalam segala bentuk penyetoran apa pun.

PT. Bank Tabungan Negara cabang Ciputat sebaikya lebih memperhatikan pengetahuan yang dimiliki karyawan, baik yang memiliki pendidikan lebih tinggi maupun yang tidak. PT. Bank Tabungan Negara, Tbk cabang Ciputat sebaiknya memberikan penghargaan kepada seluruh karyawannya. Dimana penghargaan yang diberikan kepada karyawan tidak memandang tingkat pendidikannya, baiknya penghargaan yang diberikan dengan cara sering mengadakan seminar-seminar dan mengadakan lomba-lomba mengenai perbankan. Dengan begitu pengetahuan yang didapat, baik itu karyawan yang berpendidikan tinggi maupun yang berpendidikan kurang memiliki pengetahuan yang sama, sehingga dalam pekerjaan yang berpendidikan kurang dapat juga terlibat. PT. Bank 
Tabungan Negara,Tbk cabang Ciputat sebaiknya memberikan kesempatan pada karyawan untuk bertindak lebih berani mengambil risiko dan harus ada control dari pimpinan.

PT. Bank Tabungan Negara, Tbk cabang Ciputat akan lebih selektif dalam pemberian keputusan kepada karyawan agar tidak merugikan perusahaan. PT. Bank Tabungan Negara,Tbk cabang Ciputat sebaiknya lebih meningkatkan toleransi kepada karyawan untuk menyelesaikan tugas. Dengan cara merubah peraturan yang ketat menjadi lebih fleksibel dengan memberikan batas waktu penyelesaian tugas yang cukup. Hal ini akan membuat karyawan akan lebih baik lagi dalam menyelesaikan tugas. PT. Bank Tabungan Negara,Tbk cabang ciputat sebaiknya memberikan pelatihan kepada karyawan agar dapat meningkatkan pelayanan. Pelatihan yang diberikan seperti mengadakan perlombaan dalam memberikan pelayanan. Dengan lomba pelayan terhadap konsumen maka karyawan akan lebih terlatih untuk memberikan pelayanan dengan cepat.

\section{DAFTAR PUSTAKA}

Curtis, S., Wright, D. (2001). Retaining employees the fast track to commitment. Management Research News, 24(8), 59-64. Diakses dari http://www.epsikologi.com/masalah/250702.htm

Infobank. (2012). Pujian untuk Bank NTB dan Kejutan Bank Kalsel. 10 Best Bank Service Excellence 2012, 398(XXXIV), Jakarta.

Kanungo, R. N. (1982). Measurement of Job and Work Involvement. Journal of Applied Psychology, 67: 341-349.

Kuntjoro, H. Z. Sri. (2002). Komitmen Organisasi. Jakarta.

Mangkunegara, A. P. (2000). Manajemen Sumber Daya Manusia Perusahaan. Bandung: PT Remaja Rosdakarya.

Momeni, M., Amir, B. M., Saadat, V. (2012). The relationship between organizational culture and organizational commitment in staff department of general prosecutors of Tehran. International Journal of Business and Social Science, 3(13), n/a. Diakses dari http://search.proquest.com/docview/1022663027?accountid=31532

Robbins, S., Judge. (2007). Perilaku Organisasi. Jakarta: Salemba Empat.

Sarwono, J. (2012). Path Analysis: Teori, aplikasi, prosedur analisis,untuk riset skripsi, tesis dan disertasi (Menggunakan SPSS). Jakarta: PT Elex Media Komputindo.

Setiani, A. (2011). Pengaruh Keterlibatan Kerja dan Komitmen Organisasi terhadap Kinerja Wartawan Umum Harian Suara Merdeka. Diakses pada 20 oktober 2012 dari http://journal.bakrie.ac.id/index.php/journal_MRA/article/view/46

Shah, S. M. A., Memon, M. S., Phulpoto, A. (2012) The impact of organizational culture on the organizational commitment : A study of Faculty Members of private sector Universities of Pakistan. International Journal of Contemporay Research in Business, 3(9): 1004-1016.

Stephen, P. R. et.al. (2003). Organization Behavior. Printice Hall. 
Sudarmadi. (2007). Analisis pengaruh budaya organisasi dan gaya kepemimpinan terhadap kepuasan kerja dan kinerja karyawan. Tesis Program Magister Manajemen, Universitas Diponegoro.

Triyono, F. A. (2005). Pengaruh Budaya Organisasi, Komitmen Organisasi, Kompensasi Dan Iklim Organisasi Terhadap Kinerja Karyawan PT. Bank Rakyat Indonesia (Persero) Tbk. Kantor Cabang Klaten. E-Journal STIE AUB Surakarta, 1(1). Diakses dari http://e-journal.stieaub.ac.id/index.php/excellent/article/view/49 